Relations industrielles

Industrial Relations

\title{
John Mcllroy, The Permanent Revolution? Conservative Law and the Trade Unions
}

\section{Bruce Spencer}

Volume 47, numéro 1, 1992

URI : https://id.erudit.org/iderudit/050750ar

DOI : https://doi.org/10.7202/050750ar

Aller au sommaire du numéro

Éditeur(s)

Département des relations industrielles de l'Université Laval

ISSN

0034-379X (imprimé)

1703-8138 (numérique)

Découvrir la revue

Citer ce compte rendu

Spencer, B. (1992). Compte rendu de [John Mcllroy, The Permanent Revolution? Conservative Law and the Trade Unions]. Relations industrielles / Industrial Relations, 47(1), 158-161. https://doi.org/10.7202/050750ar

Tous droits réservés @ Département des relations industrielles de l'Université Laval, 1992
Ce document est protégé par la loi sur le droit d'auteur. L'utilisation des services d'Érudit (y compris la reproduction) est assujettie à sa politique d'utilisation que vous pouvez consulter en ligne.

https://apropos.erudit.org/fr/usagers/politique-dutilisation/ 
A standard format is adopted for each part of the book. The sections begin with an overview of the topic followed by short essays and case studies. Anticipating that some readers will not be convinced of the usefulness or significance of robust unionism, several chapters contain sections entitled "A Word From the Skeptics", where Shostak debates "invisible" critics. The writing style is concise, relaxed and free of academic jargon. It is evident the author strives to portray the breadth of robust unionism rather that its depth. By robust unionism, the author is referring to numerous projects, experiments and innovations undertaken by unions (usually local unions). These undertakings reflect (1) the social consciousness and scope of union activities (i.e., the notion that unions have pushed beyond the frontiers of "pure and simple business unionism") and (2) the ability of unions to achieve major gains with minimal leverage. The book is aimed at attracting a broad readership rather than appealing to the academic community. This is not meant to suggest the book is of no interest to industrial relations scholars. On its own terms, the book is quite informative and engaging. The author has amassed a large collection of union projects worthy of illustration and raised important questions about the prospects for reviving the American labour movement.

The book does a number of things very well. First, it clearly demonstrates the diversity of unionism. Second, the book provides the philosophical and economic arguments for and against various union innovations (e.g., ESOPs). One criticism is the book merely scratches the surface on many of these issues and the emphasis generally tends to be on the pro arguments rather than the con arguments. Third, some of the cases are outstanding, including those dealing with the reorganization of air traffic controllers, the organization of support staff at Harvard University, the United Airlines' pilot strike and the strategic use of union pension funds. Given its topical nature and its emphasis on case studies, this book could have been entitled "What Else Do Union Do?"

For this reader it was a refreshing change to read about the creativity and dynamism of the American labour movement. It is not that we doubted its existence, but rather that we hear so little about it. Unfortunately, it is difficult to determine what these examples of robust unionism signify. Some may believe there is a basis for a resurgence in U.S. unionism. Others, and I suspect the majority, will point to the contradictions between robust unionism and the traditional opposition to change within the labour movement. Even Shostak acknowledges that future problems cannot be solved with yesterday's solutions.

Joseph B. Rose

McMaster University

The Permanent Revolution? Conservative Law and the Trade Unions, by John Mcllroy, Nottingham, Spokesman (for the Society of Industrial Tutors), 1991, 253 p., ISBN 0-85124-528-5

Margaret Thatcher became leader of the British Conservative Party in the mid-1970s at a time of intense debate about the direction of economic policy. The post-war consensus within British politics which had existed around government 
management of a mixed economy, including the use of tripartite bodies (government, business and trade unions), and which was targeted at low unemployment and the maintenance of universal welfare was coming apart. Inflation and unemployment were rising together and Britain appeared to be stuck with low growth rates and an increasing national debt. A radical change in policy was being urged, either more interventionist - along the lines of the alternative economic strategy, argued by the left of the Labour Party - or a free market philosophy as advocated by Milton Friedman and Hayek.

Mrs Thatcher, and her mentor Sir Keith Joseph, represented the wing of Tory opinion which believed in market freedom and less government economic intervention. Their clear vision of the way forward appealed to Conservative MPs disillusioned with Ted Heath's recent Conservative government and angry at the apparent power of the trade unions under Labour and they elected her leader. A central plank of her "free market - strong state" philosophy was legal restrictions on trade unions and, as John Mcllroy explains, this was strategically integrated with economic policy.

In power from 1979 she had ample opportunity to pursue her economic and social policies - free movement of capital, lower direct taxes, selling off publicly owned assets, reduced welfare payments, legal restrictions on trade unions and the right to strike. Outside of these areas she argued for less state intervention generally in economic and social issues (what she called giving up the "Nanny State") - and she enjoyed the benefit of substantial oil revenues to help reduce the budget deficit. But after eleven and a half years this policy cannot be heralded as successful. Unemployment has doubled, balance of payment problems have returned as has slow growth, and inflation and interest rates have remained higher than those in competitor countries. Unions have been restricted and strikes have generally been reduced. But wage settlements have not been curtailed and union membership, sector by sector is similar to the 1970s, the lower overall union density figure reflects the changing structure of the economy from large manufacturing plants to services. Even the strike figures are comparable with the decline in other countries.

It is against this background that John Mcllroy charts and assesses the six major enactments of labour law and ancillary measures since 1979. This examination is undertaken chronologically, and interwoven with other government policy, TUC and labour movement responses including brief accounts of major disputes and court cases. The overall impact of this approach is a highly readable book, authoritative and lucid which guides the reader to a greater understanding of the impact of Conservative laws AND of the possible radical alternatives.

In the first chapter Mcllroy maps out the origins of labour law and the decline of voluntarism post Second World War. He looks at the lessons Thatcher, and the judiciary, drew from the experience of the 1960s and 1970s and at the failures of the labour movement. He documents the anti-union thrust of the new conservatives peppering his text with quotes, he notes the failure of the left's counter-arguments and identifies the guiding principles of Tory legislation.

Chapters 2 to 7 outline the legislative changes brought in and explains the reactions to them noting the shifting position of the TUC and individual unions 
from opposition to "new realism" to wait and see what a Labour government can do. The miners strike (1984-5) illustrated the "growing legalisation of industrial conflict in Britain" and "the fluidity of the law and its interlocking nature" and the "potency of the key coercive legal mechanism - sequestration (of union funds)" (p. 93).

Not all Tory measures succeeded, political fund ballots and internal union elections did not go the way government wanted, but overall the legislation did restrict unions actions and forced them to work within the law. Employers who made use of the law preferred the interim injunction mechanism rather than go to full trial, others simply found the threat of legal action sufficient to curtail wild-cat strikes.

The more the government legislated the more they called for more legal restrictions on unions, in chapter 7 "Wider Still Wider" the author looks at the green papers and the 1990 Act and notes how government was still blaming the country's poor economic performance on trade unions. Although the Railway workers got a reasonable pay settlement - after some delay - working within the law, Mcliroy shows how the legislation, and judge-made law, restricted the Dockers strike bringing about defeat.

In his final chapter "Yesterday's Gone", Mcllroy begins "As the 1990s dawned it was clear that on the legislative front at least, the conservatives had won and the unions had lost." (p. 190) Living within the law proved difficult for unions, even a properly conducted ballot could be the start of legal action not a way of avoiding it. The government had seen the law as a component of its wider economic and social measures, it had remained determined to persue these objectives even when unemployment doubled. It was not afraid to use the coercive forces of the state to defeat pickets. The overall failure of government economic policy however meant that the legislative attack on unions had not paid the dividends expected. "Any success which has depended to this degree on a mixture of state coercion, high unemployment, and a greater differentiation of the labour force between the semi-employed, the low paid and those who have had real wage increases in the Thatcher years, is unlikely to constitute a permanent revolution." (p. 195)

Next, Mcllroy reviews the strategy of the TUC during the Thatcher years and the development of Labour's alternative policy. He considers it unlikely that there will be a reimposition of workers' rights (such as those in the 1975 Employment Protection Act), moreover, anything gained will be at the expense of an incomes policy or a "social contract" and will lack statutory backing for collective, organisational union rights to support the EEC social charter individual rights approach.

He argues cogently for a new approach by the labour movement, embracing positive rights and a charter of collective rights and for a debate from the bottom up as to what trade unionists want.

This is an important book that should be read in Canada alongside the Panitch and Swartz "The Assault on Trade Union Freedoms" particularly by the labour movement and by those Canadian academics who continue to believe Thatcher's policies have been "successful" in somehow turning around the UK 
economy and that a similar Canadian mix of economic and social policies, including further union restrictions will, in the end, work here.

Bruce Spencen

Athabasca University

Code du travall du Québec (législation, Jurisprudence et doctrine), $5^{e}$ édition, par Pierre Laporte, Montréal, Wilson \& Lafleur Ltée, 1991, 558 p., ISBN 2-89127-191-2

Cette $5^{e}$ édition a su demeurer fidèle au fil des années aux orientations premières des instruments de travail publiés dans la collection ALTER EGO dirigée par le professeur Hubert Reid. On y retrouve toujours en effet des informations qui permettent d'acquérir une connaissance globale de l'état du droit en vigueur enchâssé au Code du travail, ou encore d'actualiser son savoir. Outre l'intérêt certain qui en résulte pour le praticien, l'apport pour les fins de l'enseignement est évident.

Dégagée depuis quelque temps déjà d'annexes dont l'utilité avait été interrogée (voir Relations industrielles, vol. 42, no 2, 1987, p. 436), l'édition courante se consacre dorénavant exclusivement à son objet: le régime général des rapports collectifs du travail. L'auteur a néanmoins conservé l'annexe relative à la ajurisprudence sur le partage des compétences"; on y retrouve quelques renseignements sur le partage constitutionnel et sur les effets extraterritoriaux du Code.

L'ouvrage contient en un premier regroupement le texte de loi (Code du travail), ses règlements (dont le Règlement sur l'exercice du droit d'association), ainsi que les dispositions pertinentes de la Charte de la langue française. Les annotations jurisprudentielles et doctrinales sont concentrées dans une seconde partie et sont détaillées sous chacun des articles du Code.

L'auteur mentionne que le contenu est à jour au 1er janvier 1991. II n'y a cependant aucune indication sur les recueils jurisprudentiels recensés. La recherche effectuée par l'auteur et sa collaboratrice, Me Hélène Ouimet, porte sur les jugements des tribunaux supérieurs en application du Code, sur les décisions du Tribunal du travail et des arbitres de griefs. On peut se surprendre que les décisions de l'organisme spécialisé dans l'accréditation et l'exercice de la liberté syndicale, le Bureau du commissaire-général du travail, ne soient pas répertoriées; cependant, quelques décisions classiques des anciennes Commission des relations ouvrières (1944-1964) et Commission des relations du travail (1964-1969) sont rapportées. En fait les annotations privilégient les aspects institutionnels du Code du travail, dont la délimitation des compétences, pouvoirs et devoirs des organismes. Dans cette mesure on peut comprendre le choix de l'auteur puisque les principes émanent plus de l'organisme d'appel, le Tribunal du travail, que des commissaires du travail.

Le lecteur retrouve généralement sous chacun des articles une triple catégories de renseignements: de brefs résumés sur des causes pertinentes, des références globales à de la doctrine et, le cas échéant, des renvois à de la 